das gleiche Begehren nach dem Zugriff auf den Celebrity-Körper antworten. Darüber hinaus zeigt sich aus dieser Perspektive, dass mit der medientechnologisch bedingten Zitierfähigkeit von (hier: Körper-)Bildern grundsätzlich ein Moment von Enteignung einhergeht und in dieser Hinsicht Aneignungsbeziehungen auch dann nicht per se als ,unschuldig' gelten können, wenn sie sich einer Faszination verdanken. Es gibt also gute Gründe dafür, dass die Spielregeln nicht nur des game namens fame, sondern von medialen Aneignungspraktiken generell nicht allein durch technologische Machbarkeit diktiert werden, sondern Gegenstand gesellschaftlicher Aushandlungen sind, bei denen man es (wie gegenwärtig etwa in der Debatte über das weite Feld der cultural appropriation) jeweils mit sehr spezifischen Gemengelagen zu tun hat.

\title{
Beatriz Colomina \\ The 24/7 Bed: Privacy and Publicity in the Age of Social Media
}

How do we relate today when countless new technologies seem to structure every interaction? And what role does architecture play? What is the architecture of ubiquitous connectivity?

Private and public have become completely blurred. We can no longer think of distinct spaces for work, play, domesticity, and rest. We are living in a 24/7 culture. Networked electronic technologies have removed any limit to what can be done in bed. Millions of dispersed beds are taking over from concentrated office buildings. The boudoir is defeating the tower. This text explores the role of the bed as the epicenter of labor, postlabor, and love in the age of social media.

When John Lennon and Yoko Ono married secretly in Gibraltar on March 20, 1969, the ceremony lasted only three minutes. But these minutes, so elaborately protected, were in fact the end of privacy. The couple promptly invited a global audience into their honeymoon bed, a weeklong Bed-In for Peace held from March 25 to 31 in room 902 of the Amsterdam Hilton International Hotel. In a later interview in Playboy magazine, they said: "We knew our honeymoon was going to be public, anyway, so we decided to use it to make a statement. We sat in bed and talked to reporters for seven days. It was hilarious. In effect, we were doing a commercial for peace on the front page of the papers instead of a commercial for war."

John and Yoko even speak about all of this in the compact language of commercial slogans, the language of media:

1 Interviewed by David Sheff, "Playboy Interview: John Lennon and Yoko Ono," in Playboy, January 1981, p. 101. 
Yoko Ono: "In the age of advertisement, make advertisement."2 John Lennon: "There is no line between private and public. No line."3

Two of the most public people in the world, who had protested so loudly and worked so incredibly hard to protect their privacy in the face of a continuous media assault, suddenly inverted the equation and deployed the center of their private life, the bed, as a weapon, turning it into the most public platform for another kind of protest. After years of complaining about the "fishbowl" of the press and the resulting "urge for privacy," they put themselves in a literal fish bowl, the glass box of the Hilton, and created a site for work beyond paid labor:

You're in a fish bowl, so make use of it. It is no good trying to put a fence around it. So instead of all the cameras just being outside looking in, you've also got the cameras inside looking out. 4

Instead of having cameras outside snooping in, they brought the cameras inside the hotel, and further into the bedroom and onto their bed. They put the cameras to work for them. Not reporting on an event but performing the event. It was not simply a media event, it was media as event. 5

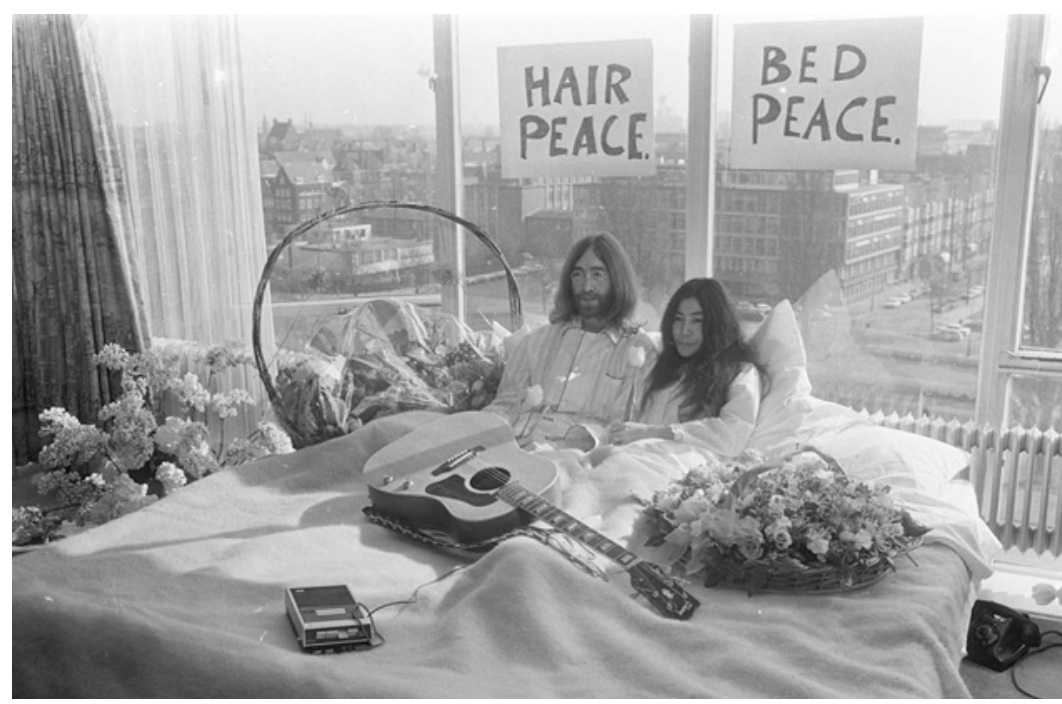

John Lenon and Yoko Ono, Bed-in for Peace, Amsterdam Hilton International Hotel, March 25, 1969

2 Yoko Ono quoted in Davidson, Sara, "Lennon and Yoko: An Alerted Press," Boston Globe, June 22, 1969, p. A34.

3 Interview by David Sheff, in Golson, G. (ed.), The Playboy Interviews with John Lennon and Yoko Ono, New York 1981, p. 92.

4 John Lennon interviewed by Leroy Aarons, "John and Yoko: Life in a 'Fish-Bowl,", in The Washington Post, Times Herald, June 15, 1969, p. 157.

5 Aarons 1969, p. 157. 
The name "Bed-In" came from "sit-in" protests and was intended as a nonviolent protest against war and to promote world peace. "Make love, not war" was the slogan of the day; but to the disappointment of journalists, John and Yoko were fully dressed: John in white pajamas, and Yoko in a long white night gown, sitting in bed, as John put it, like "angels." "I hope is not a letdown," Lennon apologized, "We wouldn't make love in public. That's an emotionally personal thing." 6

Journalists were confused by the fact that nothing seemed to happen, speaking even of their boredom: "Love-In Bores Photogs" read a Chicago headline. ${ }^{7}$ But it was a headline. Reporting a nonevent event. Nothing happening was the happening. But John and Yoko were undermining the normal understanding of what is work, what is private, what is protest, and what is an event. The bed had taken over from the street as the site of protest. They invited the world's press into their room every day between 9 a.m. and 9 p.m., treating the bed as a work space with a precise schedule, while journalists streamed in and images streamed out. To the repeated question "Why in bed?" Yoko answered that they were working really long hours and that the bed is the most comfortable place to do this.

But the work day didn't end at 9 p.m. John and Yoko repeatedly declared that they wanted to conceive a baby during that week. Yoko said that "she and Lennon 'hope to conceive a baby' during the seven days lie-in but not [in] public." 8 Symptomatically, Yoko refers here to the "Bed-In" as a "Lie-In," a slip that points to the fact that the two of them were actually working day and night. The bed is the site of 24/7 labor with a relentless schedule:

9 a.m.-9 p.m.: "Bed-In" for peace

9 p.m.-9 a.m.: "Lie-In" for insemination

The bed is both protest site and factory for baby production: a fucktory. As John put it: "It is a make-love-and-not war protest. A happening, a sex marathon, a bed production. It would be nice to conceive a baby in Amsterdam." 9 The bed as a site of conception, even an Immaculate Conception if we think about the all-white backdrop and its multiple religious references: white sheets, white night clothes, white robes, white walls, white flowers ... John talks sometimes about the couple as two angels, other times as two saints. The rhetoric is surprisingly religious with sex seemingly confined to the heterosexual marital bed and the idea of reproduction. In photographs, the room is airbrushed out so the bed appears to be floating like a cloud, with John and Yoko angelically all in white, looking directly at us, and we at them, mesmerized, perhaps wondering why we have been invited to this royal bed. Waiting for a sign. ${ }^{10}$

6 “'Love-In' Bores Photogs," in Chicago Daily Defender, March 27, 1969, p. 5.

7 "Love-In' Bores Photogs," 1969, p. 5.

8 “'Love-In' Bores Photogs," 1969, p. 5.

9 "It is Seven Days in Bed for the John Lennons," in Chicago Daily Defender, March 26, 1969, p. 2.

10 “'Love-In’ Bores Photogs,” 1969, p. 5. 
Yet we were not alone. The Bed-In received unprecedented media coverage all over the world. One room in an Amsterdam hotel became the most famous bedroom in the world. In the biggest possible expansion of the big glass windows that typically expose the domestic interior of Dutch houses, or even Amsterdam's red-light district and its famous inversion of public and private with sex workers displaying their wares to the passersby, the confusion of street and bedroom is taken to its most extreme limit. Inasmuch as John and Yoko insisted they are spending half their time trying to make a baby, they are presenting themselves as sex workers; and as spectators to the event, it was possible to sense the journalist's frustration at not being able to witness that. Reports stated that "they would engage in uninhibited love making," and journalist seemed to hang around, in the hope that something would happen, in vain. ${ }^{11} \mathrm{~A}$ kind of privacy was constructed in the middle of massive exposure. The bed oscillated between exposure and concealment.

John and Yoko didn't simply occupy the room. They redesigned it as a media stage set with a particular image in mind. They were in every sense the architects of that image. It is not by chance that the published images look so similar; practically only one angle was possible. John and Yoko had emptied the usual Hilton room, removing all the furniture, artwork, and decoration, leaving only the king-size bed, which they deliberately placed against the floor-to-ceiling glass wall, with a panoramic view onto the city of Amsterdam. With their back to the window, they faced toward the inside of the room in a kind of Loosian move.12 Their bodies against the light - in an all-white background, of white walls, white sheets, white pajamas, and white flowers seemed to fly above Amsterdam.

Outside was, of course, Amsterdam, but the bed was far more public than the streets. Rather than contemplate the view of the city, its occupants faced the reporters' cameras, registering the images and sounds that would soon be in the streets, in newspapers and magazine covers, on TV, film, and radio, internationally. For twelve hours each day, John Lennon and Yoko Ono did endless interviews on camera or by telephone, often doing more than one interview at once. Celebrities came and went. The telephone rang constantly. No second was empty: "We don't have time to be bored." 13

On the glass panes behind them, the couple pinned up two hand-written posters: "BED PEACE" and "HAIR PEACE;" and on the side wall: "STAY IN BED," "GROW YOUR HAIR," "I LOVE YOKO," "I LOVE JOHN," and "BAGISM." From the street, the back of the two posters was visible, marking the nowfamous room, and even the bed, with the white pillows pushed up against the

11 “'Love-In’ Bores Photogs,” 1969, p. 5.

12 Adolf Loos always placed the couch against the window with the occupants facing the interior, turning them into a silhouette against the light for those entering the room. See Colomina, Beatriz, Privacy and Publicity: Modern Architecture as Mass Media, Cambridge, MA 1994.

13 "Beetle Show Not Over Yet, Lennon Feels: From Amsterdam Bed He Disagrees with Ringo on Concerts," in The Sun, Baltimore, March 29, 1969, p. A3. 
glass, and at times the back of John and Yoko's heads were visible as the two of them held court.

All the usual furniture went out, and in came media equipment, filling the room and even the bed itself, which was covered with tape recorders, telephones, microphones, and flowers from the wedding. Indian music played from a phonograph. The room was permanently crowded with journalists who leaned forward, so close they were practically on the bed, where they would deposit their equipment and ask questions. They seemed to be puzzled, waiting for something to happen, while John and Yoko talked endlessly about peace and exuded a strange calm. What was happening was a happening. Ono was a key Fluxus artist, a legend of downtown Manhattan performance art, and the Bed-In was, first of all, and maybe never more than, a performance work. ${ }^{14}$ It continued the provocation of Ono's Cut Piece of 1964 where the audience was invited to come on stage one by one and cut away a small piece of her clothing with a pair of scissors. Ono sat without any response as the line between public and private was literally cut through. The Bed-In was likewise an artwork, a 24/7 piece by two hyperdedicated art workers, challenging assumptions between what is inside and what is outside, what is everyday and what is performance.

In fact, the performance and the couple's personal relationship itself began with an artwork. The Bed-In in Amsterdam was not the first bed as production site, nor the first 24/7. In their first collaborative work in May 1968, John and Yoko composed and recorded experimental music in an all-night session that ended in the morning with their, reportedly, first time making love. Lennon took some pictures of themselves with his automatic camera, naked with the unmade bed in the background. The images were used in the front and back cover of the album Unfinished Music n.1-Two Virgins, produced by Apple Records. The album covers were ruled obscene in the United States, confiscated in the docks of New Jersey, and ordered destroyed.15 They were finally distributed with the covers wrapped in brown paper with hole on both the front and back covers showing only their faces - which, like all forms of prohibition, only intensified the erotic charge. A kind of peephole. These original photographs already capture the angelic scene of the cloudlike bed. The unmade bed and the two naked artists standing at its foot with the rumpled sheets on the floor float at the center of the white album cover. In the typewritten text below, Paul McCartney symptomatically refers to the meeting of "two saints." Everything that will appear in Amsterdam had already been put in motion in London a year before. The scandalizing image lured the world into the Hilton.

14 As Martha Ann Bari's dissertation put it: "Part media circus, part consciousness-raising session, part pajama party, and part jam session, the Amsterdam and Montreal Bed-Ins transformed life into performance art.” See Bari, Martha Ann, "Mass Media is the Message: Yoko Ono and John Lennon's 1969 Year of Peace,” PhD Diss., University of Maryland 2007, p. 81.

15 Bari 2007, p. 33-34. 


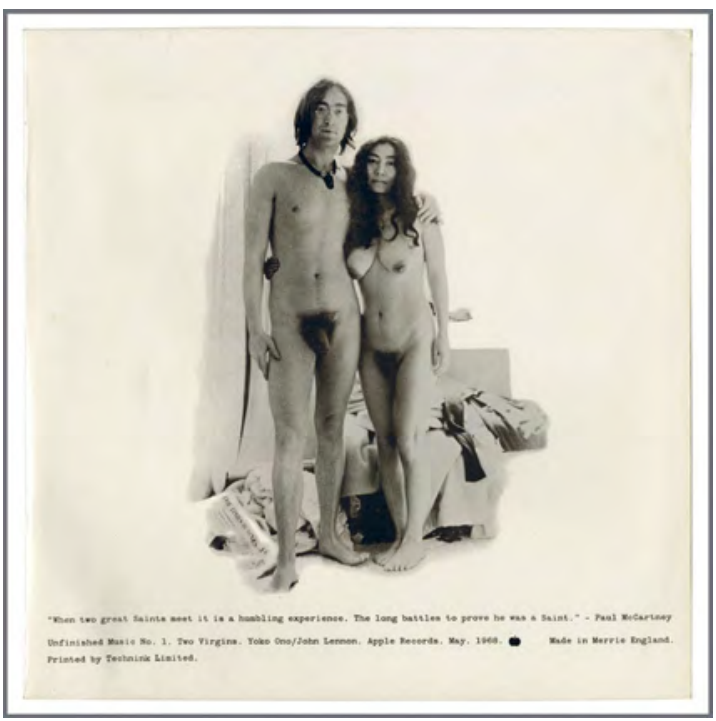

Front cover of Two Virgins album, 1968.

But why the Amsterdam Hilton? "Because it's very functional. The bed is okay,"16 Lennon laconically replied. The choice was no accident. The Hilton International was already a "fish-bowl." The guests are not simply seen by other guests, as in a traditional grand hotel. The entire scene is designed to expose them, with transparent walls not just in the lobby but in the rooms themselves, which were equipped with balconies to make appearances. The hotels are not just a voyeur's paradise, but an exhibitionist one. The architectural equivalent of the reversal of the fishbowl of the media that Lennon and Ono wanted to perform with their bed-in was ready-made in the all-glass Hilton International hotels. Hilton turned what people fear - exposure - into a positive experience. As Anabelle Wharton puts it, the Hilton chain "transformed the anxiety of being observed into a pleasure." 17 In 1965, Vogue magazine described the "subliminal pleasures" of the "tall glass oasis" operating as "a balm, a salve, a glass of Alka-Seltzer," in the face of the stress of the unfamiliar. 18

The hotel is in the city, but detached; a transparent oasis. But what is outside? The background is Amsterdam, at the time the center of Europe's 1960s cultural and sexual revolution, of experimentation with sex, drugs, rock ' $n$ ' roll, political activism, and protest - against the Vietnam war, the local government, and housing shortages; for equal rights, abortion, and even alternative forms of transportation. The Dutch anarchist movement Provo provoked

16 “It is Seven Days in Bed for the John Lennons," March 26, 1969, p. 2.

17 Wharton, Annabel Jane, Building the Cold War: Hilton International Hotels and Modern Architecture, Chicago 2001, p. 5.

18 Bradshaw, George, "The View form a Tall Glass Oasis: The Subliminal Pleasures of Hilton Hotels," in Vogue 146 (July 1965), p. 126. 
The whole room was set up as a TV studio with spotlights on top of the bed. The happening was a collaboration with a Canadian TV corporation, which recorded all the interviews, and with celebrity visitors such as the Smothers Brothers, Derek Taylor, Murray the K, the Canadian Radha Krishna, and Timothy Leary, who even lay in bed with the couple. It was a kind of protoreality TV for which Amsterdam and Toronto now appeared as rehearsals that had themselves been broadcast.

In an unsympathetic review of the TV program "John and Yoko Lennon's Bed-In for Peace," filmed in Montreal, Variety magazine wrote: "It was lensed like disaster coverage, and steadier camera handling has come out of combat zones."21 The Vietnam war was indeed never far away from the coverage of the Bed-In, and on many occasions it occupied the same page of the newspaper. When the Boston Globe reported on a Newton couple that had emulated John and Yoko, staying 144 hours in bed in protest against the war, for instance, beneath it a story ran about the tenth anniversary of the first soldier killed in Vietnam and about four Massachusetts' towns that had commemorated the 35,000 American soldiers who had died in Vietnam until then by holding a "mock funeral procession."22

The Montreal Bed-In week culminated with the recording of "Give Peace a Chance," somehow echoing the origins of the Bed-In in a recording session in London. John and Yoko were thoroughly mediatic in their sensitivity to the relationship between the singular event and the permanent recording, the single bed and the mass audience. The bed was literally suspended in fronts of millions of eyes, floating in media space with one idea in mind, even a product. As Yoko Ono put it: "We're selling peace like we're selling soap."23

The 24/7 bed of John Lennon and Yoko Ono anticipates the working bed of today. In what is probably now a conservative estimate, the Wall Street Journal reported in 2012 that 80 percent of young New York City professionals work regularly from bed. The fantasy of the home office has given way to the reality of the bed office. The very meaning of the word "office" has been transformed. Millions of dispersed beds are taking over from office buildings. The boudoir is defeating the tower. Networked electronic technologies have removed any limit to what can be done in bed. But how did we get here?

20 For more on the Montreal event, see Rumpfhuber, Andreas, "Working Glamour," in Rumpfhuber (ed.) Into the Great Wide Open, Barcelona 2017.

21 "John and Yoko Lennon's Bed-In for Peace," with John and Yoko Lennon, Stuart Klein, and others, Crystal Records, WNEW-TV, New York, prod. Ted Kavanan, writer Stuart Klein, “Televisions Reviews," in Variety Magazine, June 25, 1969, p. 24.

22 “144 Hour Bed-In by Newton Couple," in Boston Globe, July 8, 1969, p. 25.

23 John Lennon with Tom Campbell and Bill Hollery, "The KYA 1969 Peace Talk," side one, 45 rpm record (San Francisco: KYA Radio 1260, 1969). Quoted in Bari 2007, p. 9. 


\section{COLLABORATE IN BED}

\section{...OR AT WORK.}

Sometimes your best work happens away from the office. With Bluebeam ${ }^{\otimes}$ Studio $^{\mathrm{TM}}$, you can store and manage an unlimited number of PDFs or any other file type in the cloud, for free. Start a Studio session with project partners around the world and easily collaborate in real time, or any time, with shared PDF comments and markups.

Anything is possible. www.bluebeam.com/automate

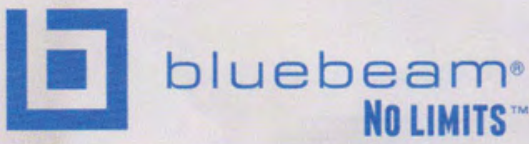


In his famous short text "Louis-Philippe, or the Interior," Walter Benjamin wrote of the splitting of work and home in the nineteenth century:

Under Louis-Philippe, the private citizen enters the stage of history. ... For the private person, living space becomes, for the first time, antithetical to the place of work. The former is constituted by the interior; the office is its complement. The private person who squares his accounts with reality in his office demands that his interior be maintained in his illusions. ... From this spring the phantasmagorias of the interior. For the private individual the private environment represents the universe. In it he gathers remote places and the past. His living room is a box in the world theater. ${ }^{24}$

Industrialization brought with it the eight-hour shift and the radical separation between the home and the office or factory, between rest and work, night and day. Postindustrialization collapses work back into the home and takes it further into the bedroom and into the bed itself. Phantasmagoria no longer line the room in wallpaper, fabric, images, and objects. It is now within electronic devices. The whole universe is concentrated on a small screen with the bed floating in an infinite sea of information.

To lie down is not to rest but to move. The bed is now a site of action. But the voluntary invalid has no need of their legs. The bed has become the ultimate prosthetic and a whole new industry is devoted to providing contraptions to facilitate work while lying down - reading, writing, texting, recording, broadcasting, listening, talking, and, of course, eating, drinking, sleeping, or making love - activities that seem to have themselves been turned, of late, into work. Waiters in restaurants in the United States ask if you are "still working on that" before removing your plate or your glass. Endless advice is dispensed about how to "work" on your personal relationships, "schedule" sex with your partner. Sleeping is definitely hard work too, for millions, with the psychopharmaceutical industry providing new drugs every year, sleep monitors on watches, and an army of sleep experts providing advice on how to achieve this apparently ever-more-elusive goal - all in the name of higher productivity, of course.

This philosophy was already embodied in the figure of Hugh Hefner, who famously almost never left his bed, let alone his house. He literally moved his office to his bed in $\mathbf{1 9 6 0}$ when he moved into the Playboy Mansion at $\mathbf{1 3 4 0}$ North State Parkway, Chicago, turning his bed into the epicenter of a global empire, and his silk pajamas and dressing gown into his business attire. "I don't go out of the house at all!!! ... I am a contemporary recluse," he told Tom Wolfe, guessing that the last time he was out had been three and a half

24 Walter Benjamin, "Louis-Philippe, or the Interior," in Demetz, Peter (ed.), Reflections: Essays, Aphorisms, Autobiographical Writings, trans. Edmund Jephcott, New York 1978, p. 154. 
months before, and that in the last two years he had been out of the house only nine times. ${ }^{25}$ Fascinated, Wolfe described him as "the tender-tympany green heart of an artichoke." 26

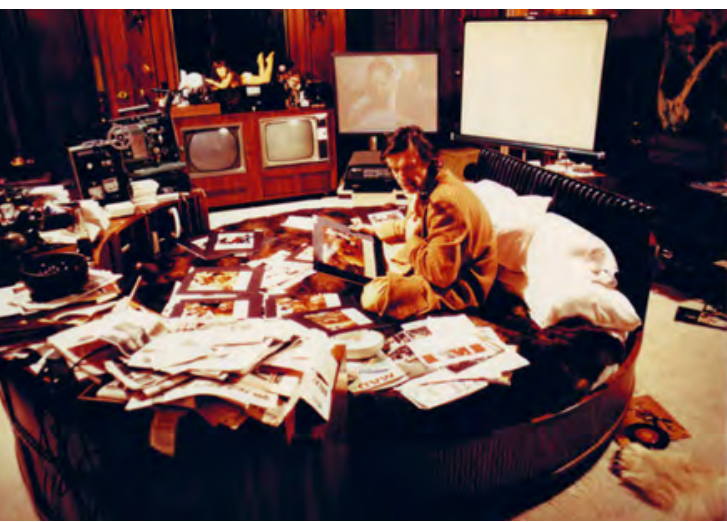

Hugh Hefner in bed, 1966

Playboy turned the bed into a workplace. Of course, a huge backstage labor force was required to enable Hefner to stay in bed. The man in bed constructing fantasies about the girl next door was supported by an army of unseen women at home. It also required a huge technical backstage. From the mid-1950s on, the bed became increasingly sophisticated, outfitted with all sorts of entertainment and communication devices as a kind of control room. Playboy devoted many articles to the design of the perfect bed. Hefner acted as the model with his famous circular bed in the Playboy Mansion. The bed was first introduced as a feature in the "Playboy Townhouse" article of 1962, which presents a detailed unrealized project in plans, sections, and renderings that had been originally commissioned to be Hefner's own house. Not by chance, the only piece of the design to be realized was the bed, which was installed in the mansion. The bed itself was a house. Its rotating and vibrating structure was packed with a small fridge, hi-fi, telephone, filing cabinets, bar, microphone, dictaphone, video cameras, headphones, TV, breakfast table, work surfaces, and control for all the lighting fixtures - all for the man who never wanted to leave. The bed was Hefner's office, his place of business, where he conducted interviews, made his phone calls, selected images, adjusted layouts, edited texts, ate, drank, and consulted with playmates. Sex was part of his work, part of his business. He was a sex-worker in the end.

Hefner was not alone. The bed may have been the ultimate midcentury American office. In an interview in the Paris Review in 1957, Truman Capote is asked, "What are some of your writing habits? Do you use a desk? Do you write on a machine?" To which he answers:

25 Wolfe, Tom, “King of the Status Dropouts," The Pump House Gang, New York 1965.

26 Wolfe 1965, p. 63. 
I am a completely horizontal author ... I can't think unless I'm lying down, either in bed or stretched on a couch and with a cigarette and coffee handy. I've got to be puffing and sipping. As the afternoon wears on, I shift from coffee to mint tea to sherry to martinis. No, I don't use a typewriter. Not in the beginning. I write my first version in long-hand (pencil). Then I do a complete revision, also long-hand.

[...]

Then I type a third draft on yellow paper. No, I don't get out of bed to do this ... I balance the machine on my knees. Sure, it works fine ... I can manage a hundred words a minute. ${ }^{27}$

From morning to afternoon to evening, the drinks, the paper, and the equipment changes, but Capote's position on the bed does not. Even architects set up offices in bed at midcentury. Richard Neutra started working the moment he woke up with elaborate equipment enabling him to design, write, or even interview in bed. As his son Dion Neutra revealed:

Dad's best time for creative thinking was early in the morning, long before any activity had started in the office below. He often stayed in bed working with ideas and designs, even extending into appointments which had been made earlier. His one concession to convention was to put on a tie over his night shirt when receiving visitors while still propped up in bed!28

Neutra's bed in the VDL house in Silverlake, Los Angeles, included two public phones; three communication stations for talking with other rooms in the house, the office below, and another half a kilometer away; three different call bells; drafting boards and easels that folded down over the bed; electric lights; and a radio-gramophone controlled from a dashboard overhead. A bedside table rolling on casters held the tape recorder, electric clock, and storage compartments for drawing and writing equipment so that Neutra could, as as put it in a letter to his sister, "use every minute from morning to late night." 29

Postwar America inaugurated the high-performance bed as an epicenter of productivity, a new form of industrialization that was exported globally and has now become available to an international army of dispersed but interconnected producers. A new kind of factory without walls is constructed by compact electronics and extra pillows for the $24 / 7$ generation.

27 “Truman Capote, The Art of Fiction No. 17," interviewed by Patti Hill, in The Paris Review 16, Spring-Summer 1957, p. 46 and p. 48; ellipses in the original, omitted text marked with ellipses in brackets.

28 Neutra, Dion, "The Neutra Genius: Innovation \& Vision," in Modernism 1, no. 3, December 1998. 
The kind of equipment that Hefner envisioned (some of which, like the answering machine, didn't yet exist) has now become expanded for the internet and social media generation, who not only work in bed but socialize in bed, exercise in bed, read the news in bed, and entertain sexual relationships with people miles away in bed. The Playboy fantasy of the nice girl next door is more likely realized today with someone on another continent than in the same building or neighborhood - a person you may have never seen before and may never see again. And it is anybody's guess if she is actually real, or rather an electronic construction. As in the Spike Jonze's film Her, a depiction of life in the soft, uterine state that is a corollary to our new mobile technologies, the "her" in question is an operating system that turns out to be a more satisfying partner than a person. A male fantasy in which the protagonist lies in bed with Her, chatting, arguing, making love and eventually breaking up, still in bed.

If, according to Jonathan Crary, capitalism is the end of sleep, colonizing every minute of our lives for production and consumption, the actions of the voluntary recluse are not so voluntary in the end..$^{30}$ But it may be worth noting that communism had its own ideas of bringing the bed to the workplace. In 1929, at the height of Stalin's first five-year plan - with the working day extended and mass exhaustion among factory workers in the face of staggering production quotas - the Soviet government organized a competition for a new city of rest for 100,000 workers. Konstantin Melnikov presented the "Sonata of Sleep," a new building type for collective sleep, with mechanized beds rocking the workers to unconsciousness and slanted floors to eliminate the need for pillows.

Centralized control booths with sleep attendants would regulate temperature, humidity, smell, and even sounds to maximize sleep, including the "rustles of leaves, the cooing of nightingales and the soft murmur of waves." 31 Melnikov described it as a "laboratory of sleep" and made a poster that reads: "Cure through sleep and thereby alter the character." The inspiration was symptomatically American - Melnikov had read about a military academy in Pensacola, Florida, that taught language to sleeping cadets. Sleep itself had become part of the industrial process.

29 Richard Neutra to Verena Saslavsky (December 4, 1953), Dion Neutra Papers, quoted in Hines, Thomas S. Richard Neutral and the Search for Modern Architecture: A Biography and History, Los Angeles 1982, p. 251.

30 Crary 2013.

31 Starr, S. Frederick, Melnikov: Solo Architect in a Mass Society, Princeton 1978, p. 179. See also Wood, Tony. "Bodies at Rest," in Cabinet 24, Winter 2006-2007. 
The nineteenth-century division of the city between rest and work may soon become obsolete. Not only have our habits and habitats changed with the internet and social media, but predictions about the end of human labor in the wake of new technologies and robotization that were already being made at the end of the nineteenth century are no longer treated as futuristic. Thirtyfive years ago, the late economist Wassily Leontief reminded us that "They replaced horses, didn't they?" and the business section of The New York Times recently reconsidered his idea of the end of the "human workhorse":

Horses hung around in the labor force for quite some time after they were first challenged by "modern" communications technologies like the telegraph and the railroad, hauling stuff and people around farms and cities. But when the internal combustion engine came along, horses - as a critical component of the world economy - were history. ... Humans as workhorses might also be on the way out. ${ }^{32}$

Economists wonder what kind of economic model this reality will lead to: from growing inequalities with a vast number of people unemployed to large-scale redistribution in the form of Universal Basic Income, which was recently considered in a referendum in Switzerland and rejected. Yet multiple trials are now underway from California to Finland.

The end of paid labor and its replacement with creative leisure was already envisioned in utopian projects of the 1960s and 1970s by Constant, Superstudio, and Archizoom, including hyperequipped beds. Meanwhile the city has started to redesign itself.

In today's attention-deficit-disorder society, we have discovered that we work better in short bursts punctuated by rest. Many companies provide sleeping pods in the office to maximize productivity. Bed and office are never far apart in the 24/7 world. Special self-enclosed beds have been designed for office spaces - turning themselves into compact sealed capsules, mini space ships that can be used in isolation, gathered together in clusters, or lined up in rows for synchronized sleep - understood as a part of work rather than its opposite. Between the bed in the office and the office in the bed, a whole new horizontal architecture has taken over. It is magnified by the flat networks of social media that have themselves become fully integrated into professional, business, and industrial environments in a collapse of traditional distinctions between private and public, work and play, rest and action. The bed itself with its ever more sophisticated mattress, linings, and technical attachments is the basis of an intra-uterine environment that combines the sense of deep interiority with the sense of hyperconnectivity to the outside. Not by chance, Hefner's round bed was a kind of flying saucer hovering in space in a room without windows, as if in orbit, with the TV hanging above as a reference to

32 Porter, Eduardo, "Contemplating the End of the Human Workhorse," in The New York Times, June 8, 2016, pp. B1 and B6. 
planet earth. It was a circle, the classical image of the universe, after all. The bed today has become a portable universe, equipped with every possible technology of communication. A midcentury fantasy has turned into mass reality. Working in bed in the gig economy is increasingly becoming a norm for the marginalized and disenfranchised. It is no longer about the quasi-aristocratic, or dandy, male figure laboring in bed but a shift in the organization of labor, perhaps at the threshold of postlabor. The bed has become infrastructural, a crucial node floating in global networks.

What is the architecture of this new space and time? What is the nature of this new interior in which we have collectively decided to check ourselves in? What is the architecture of this prison in which night and day, work and play are no longer differentiated and we are permanently under surveillance, even as we sleep in the control booth? New media turns us all into inmates, even as we celebrate endless connectivity. We have all become "a contemporary recluse," as Hefner put it half a century ago.

In Laura Poitra's film Citizenfour, we see Edward Snowden up close for days on end sitting on his bed in a Hong Kong hotel, surrounded by laptops, communicating with journalists in the room and around the world about the secret world of massive global surveillance. The biggest invasion of privacy in the history of the planet is revealed from bed and dominates all media. The most public figure in the world at that moment is a recluse. Architecture has been inverted.

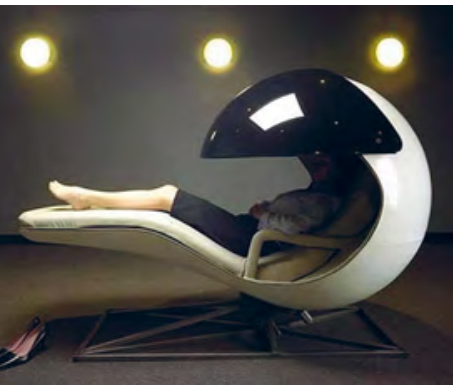

EnergyPod by MetroNaps, "the world's first chair designed for napping in the work place,“ 2007

\section{Dennis Pohl \\ Tools, Infrastrukturen und Räume des relationalen Forschens \\ Tools, Infrastructures, and Spaces of Relational Research}

Die Vermittlung von Wissen ist stets medial gebunden. Medien sind wiederum Teil des normierten Regelwerks einer Infrastruktur, worunter Keller Easterling eine „diffuse 